\title{
Landavensium Ordo Chartarum
}

\section{Author(s): Alfred Anscombe}

Source: The Celtic Review, Vol. 6, No. 22 (Oct., 1909), pp. 123-129

Stable URL: http://www.jstor.org/stable/30070209

\section{Accessed: 14-06-2016 04:23 UTC}

Your use of the JSTOR archive indicates your acceptance of the Terms \& Conditions of Use, available at

http://about.jstor.org/terms

JSTOR is a not-for-profit service that helps scholars, researchers, and students discover, use, and build upon a wide range of content in a trusted digital archive. We use information technology and tools to increase productivity and facilitate new forms of scholarship. For more information about JSTOR, please contact support@jstor.org. 


\section{LANDAVENSIUM ORDO CHARTARUM}

\section{Alfred Anscombe}

The chartulary of the ancient church of Llandaff deserves to be numbered among the most venerable of the many monuments of Latin Christianity which have originated in countries beyond the borders of Italy. The series of charters it preserves begins in the middle of the fifth century, and runs onward for seven hundred years. The study of the earliest documents of the series is complicated and difficult. This is owing partly to their isolated antiquity; but chiefly to the fact that no chronographical data whatever appear in any one of them until we have penetrated to the middle of the tenth century. This curious feature of the Llandaff charters has hitherto met with only slight recognition. It must be obvious, however, that the views of the collective value of the charters of any particular period are, in the circumstances, merely tentative, and that conclusions based upon those views cannot avoid being unreliable. Real progress, in short, cannot be made in research in connection with these documents until they have been arranged in their due and proper order.

The criteria of distribution are numerous and reliable. The lists of witnesses-royal, prelatic, clerical, and layare fairly full, and from time to time we get a note of sonship, or even of more remote descent, and of motherhood, also, in reference to princely families. There are four methods of arrangement available : (1) by the bishops ; (2) by the kings ; (3) by the abbots of the diocese, of whom the three principal ones are named and identified in many charters; and (4) by any two or more of the preceding methods employed concurrently. The first two methods are so obvious that I need not comment upon their use. The third has not been adopted as yet by any investigator. 
Its ratio is this : In the second half of the fifth century three eminent British ecclesiastics, named Catoc, Ildut, and Dochu, founded abbeys in the bishopric of Llandaff. Their successors in the sixth century are respectively styled: (1) abbas altaris Sancti Catoci, or Carbani Uallis, or Nant Carban; (2) abbas Sancti Ilduti, or Ilduti, or Lannildut; (3) abbas Docunni, or Docguinni, or Dochou. Whether the three abbeys were founded in the order in which $I$ have named them, I cannot say. But this is the order of precedence, and, except in a few instances, it is the order in which the three abbots subscribed the deeds they witnessed to. Now, in the time of Bishop Oudoceus at least twenty grants were made to his church. Fifteen of these preserve the names and abbacies of fifteen successive abbots, and it should follow that the threefold course of concurrent tenancy must have been broken so frequently, that the succession of the abbots ought to be exactly determinable, and the chronological order of the grants themselves be no less clearly revealed. In the following tables we get, first, the order of the names as they are given in the chartulary; second, the true order. The arabic numbers indicate the first; the capital letters the second. $C, I$, and $D$ indicate the abbeys. The commas show that the preceding name on the same line reappears.

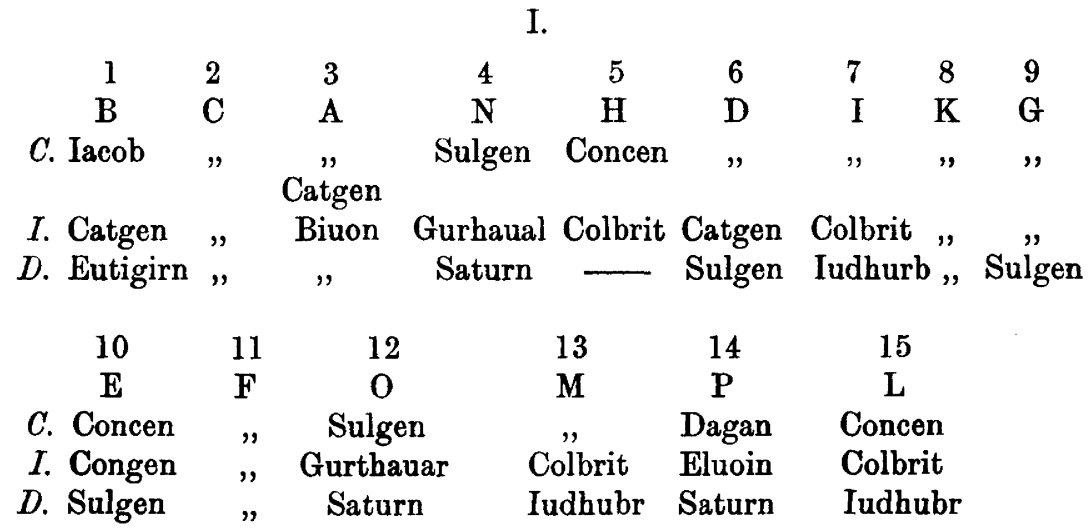

The method of compilation of the chartulary of Llandaff. 
for Oudoceus's times, is quite clear : the register or compiler knew that Iacob was abbot of Llangatoc at Oudoceus's consecration, and took three 'Iacob' deeds. He then, quite by chance, and out of order, transcribed a 'Sulgen' deed. He detected his error, and copied all the 'Concen' grants he had, except one, and then completed the 'Sulgen' ones. After that he wrote out the 'Dagan' charter in the last place but one under Oudoceus, and then transcribed the 'Concen' deed he had passed over. The broken succession is clearly indicated by the recurrence of names in the wrong places, and the true chronological order of the three abbots, and of the grants they witnessed in Oudoceus's day is as follows :-

II.

\begin{tabular}{|c|c|c|c|c|c|c|c|}
\hline 3 & 1 & 6 & 10 & 11 & 9 & $\begin{array}{r}\mathbf{5} \\
\mathrm{H}\end{array}$ & 7 \\
\hline A & B & C $\quad$ D & E & F & G & $\mathrm{H}$ & \\
\hline C. Iacob & & „Conce & & $"$ & & $"$ & $"$ \\
\hline I. Biuon & Catgen & $"$, & Congen & ", & Colbrit & ", & \\
\hline$D$. Eutigirn & $"$ & , Sulge & en & $"$ & , & * & Iudhurb \\
\hline 8 & 15 & 13 & 4 & 12 & 14 & & \\
\hline $\mathbf{K}$ & $\mathbf{L}$ & $\mathbf{M}$ & $\mathrm{N}$ & 0 & $\mathbf{P}$ & & \\
\hline C. Concen & , & Sulgen & & , & Dagan & & \\
\hline I. Colbrit & $"$ & " & Gurthauar & , & Eluoin & & \\
\hline$D$. Iudhubr & $"$ & $"$ & Saturn & ", & $"$ & & \\
\hline
\end{tabular}

In the second instalment of this series $I$ hope to be allowed to apply this criterion to the questions involved in the re-arrangement of the documents relating to Bishop Oudoceus, ca. 520. In this paper I shall only deal with the grants made to Dubricius and his suffragans. 


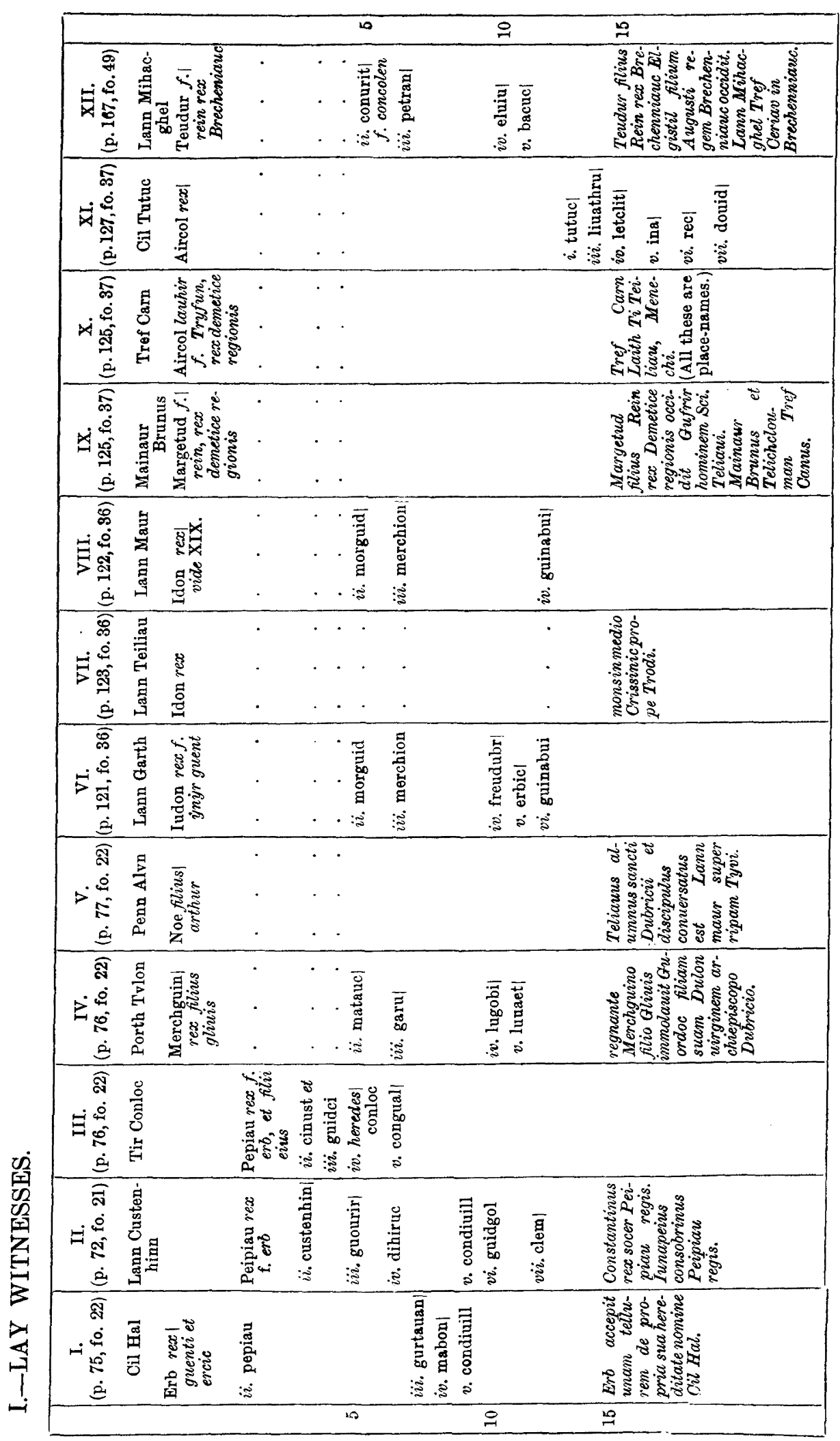




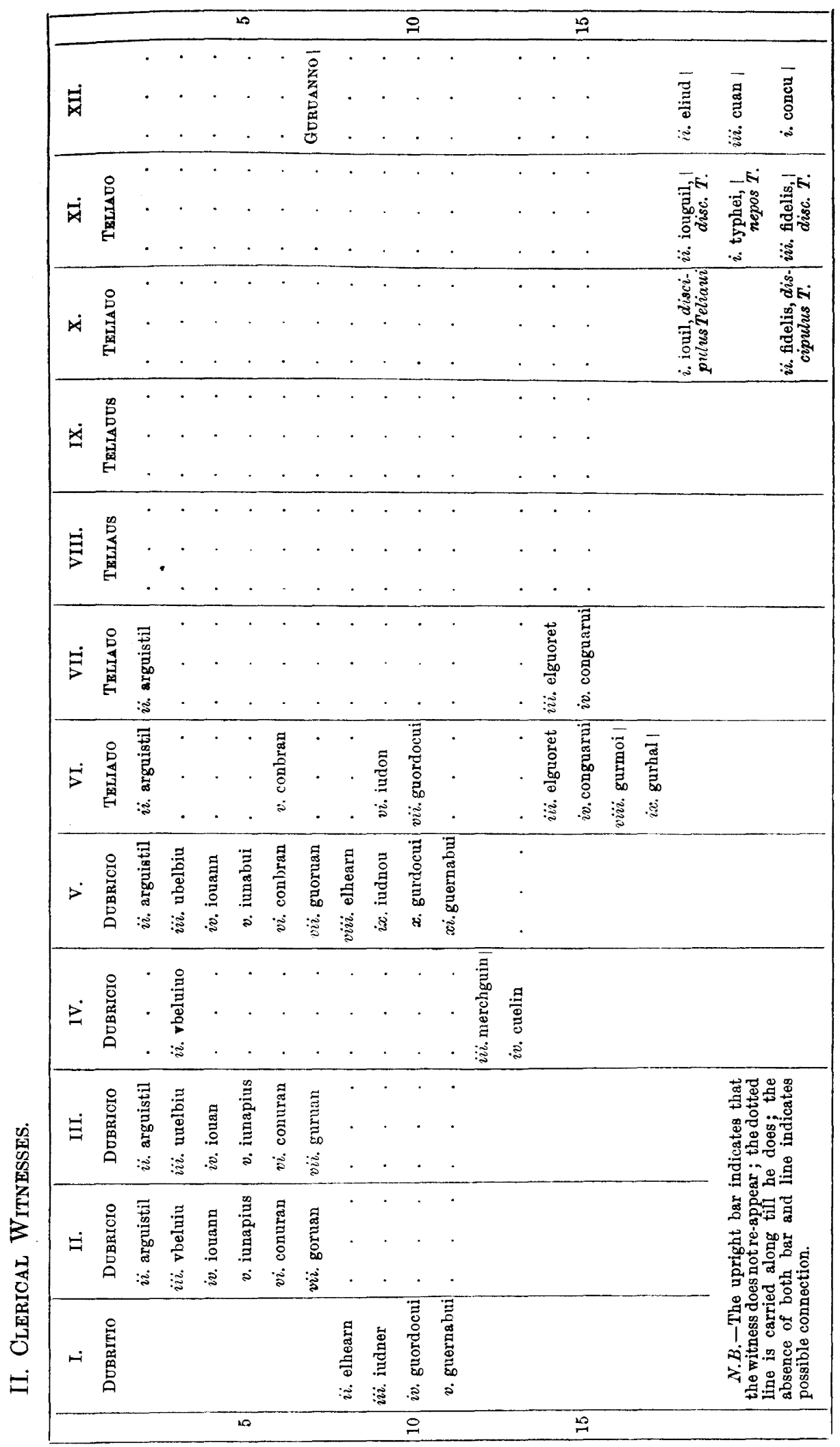




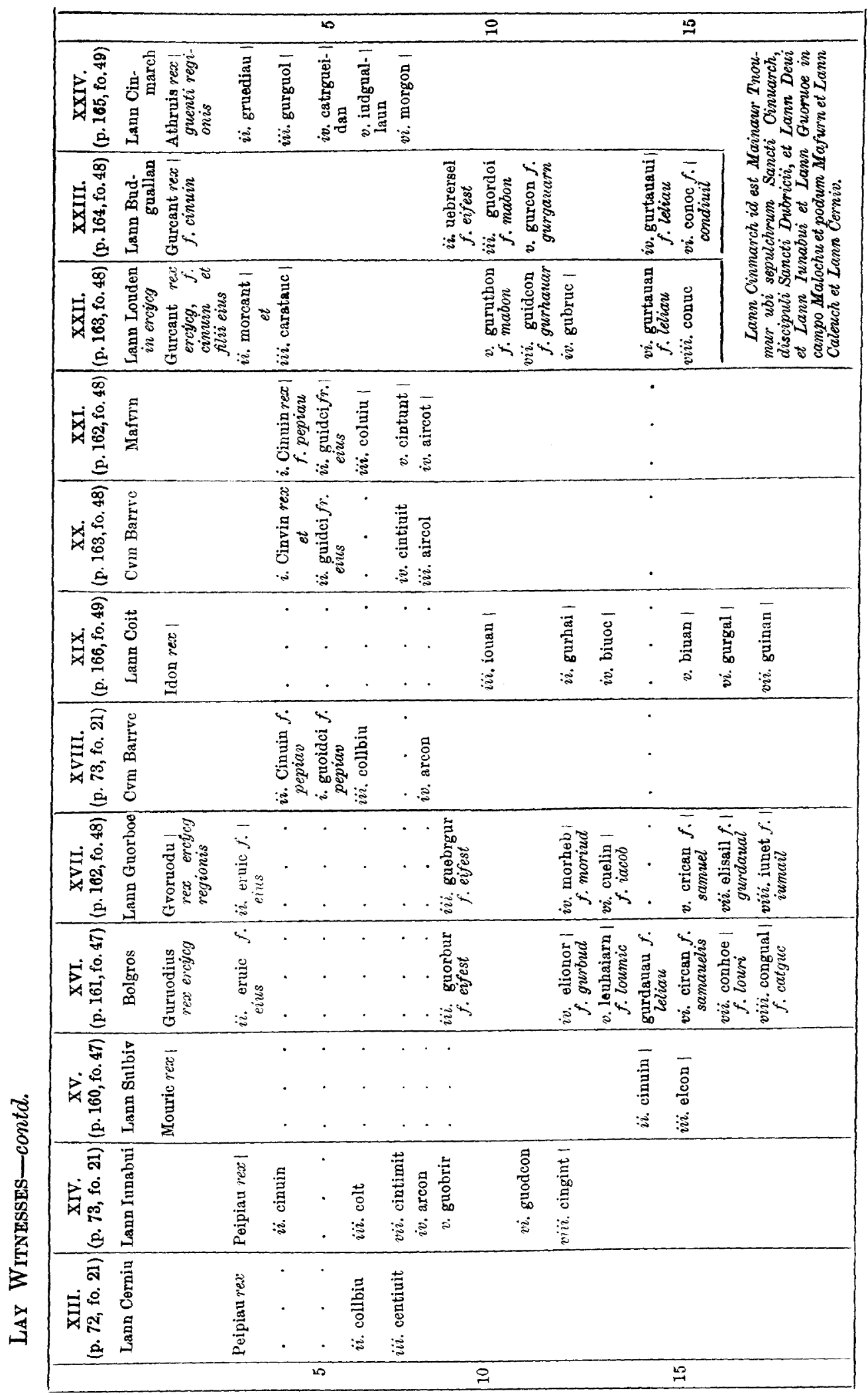




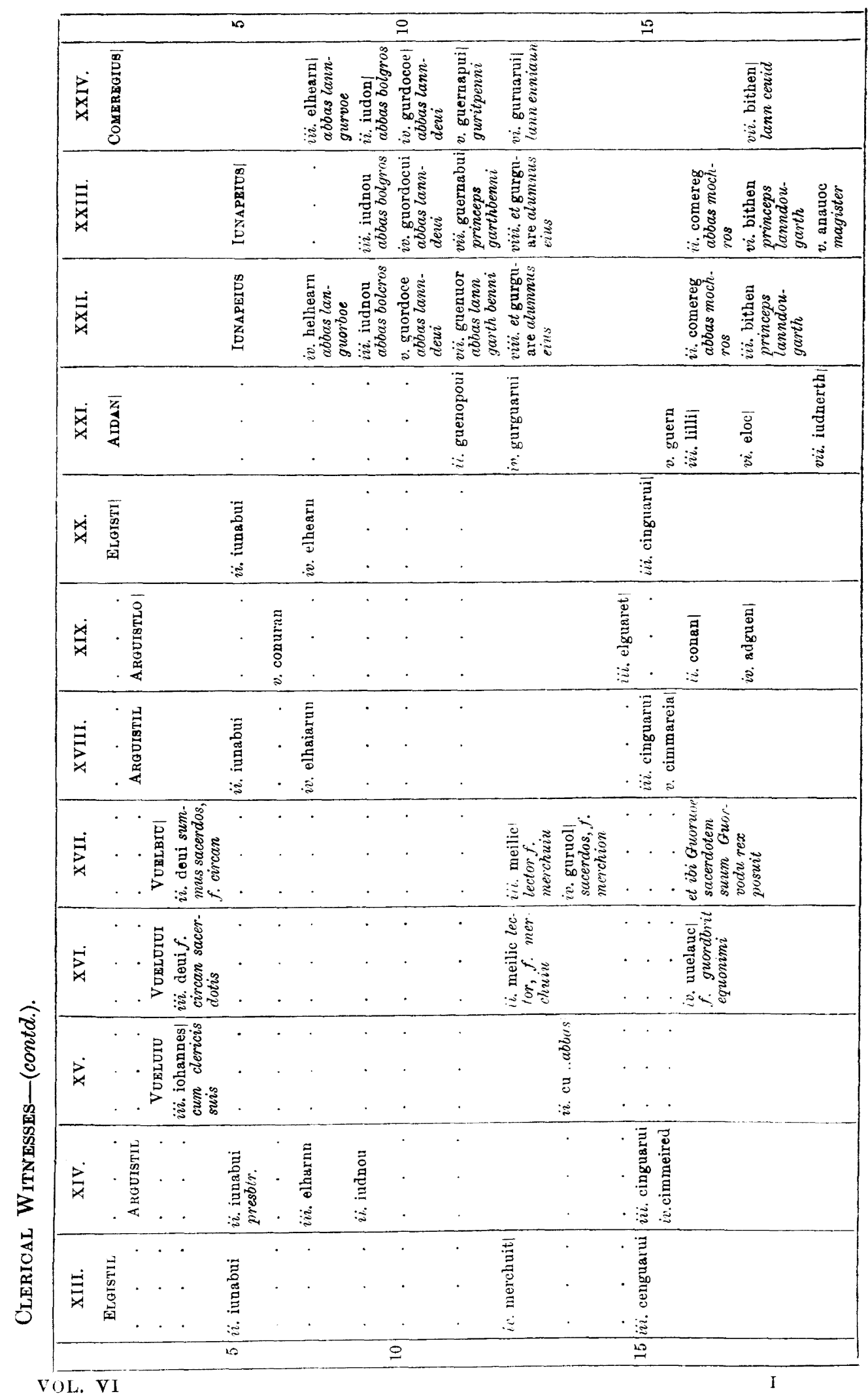

